\title{
FROM WAHHABISM TO ISLAMIC EXTREMISM: RUSSIA CONFRONTING ISLAMISM IN CONFLICTS AT HOME AND ABROAD
}

\author{
Noa Gur-Arie \\ New York University School of Law
}

ORCID: 0000-0002-1975-8052

(C) N.Gur-Arie, 2021

DOI: $10.20542 / 2307-1494-2021-2-174-185$

\begin{abstract}
The article explores the evolving role of Islamism in Russian national security discourse from the post-Soviet conflicts in the North Caucasus to present Russian engagement in Syria. It traces the development of the term "Wahhabi" as a shorthand for Islamist practices, including subversive and violent activity, and how that label has come to be replaced by an even more amorphous specter of "international terrorists" as the main source of such threats. The article concludes that in Russia, as in many other countries, the arbitrary divide between "good Muslims" and "bad Muslims" in national security discourse is largely subordinate to, and serves to obscure, more important realpolitik aims.
\end{abstract}

Keywords Islam, radical Islamism, Russia, Chechnya, Syria, Wahhabism, terrorism, Soviet Union, Afghanistan

\section{Название статьи \\ От ваххабизма к исламскому экстремизму: Россия и противодействие исламизму в конфллитах внутри страны и за рубежом}

Аннотация В статье анализируется эволюция понятия «исламизм» в российском дискурсе по проблемам национальной безопасности, от периода вооруженного противостояния на Северном Кавказе до продолжающегося участия РФ в регулировании конфликта в Сирии. Отслеживается, как применение на более ранних стадиях термина «ваххабизм» для обозначения исламистских, в т. ч. подрывных и насильственных, практик сменилось преобладанием аморфного спектра «международных террористов» как обозначения основного источника угроз этого типа. Сделан вывод о том, что в России, как и во многих других странах, проведение границы между «хорошими» и «плохими» мусульманами в дискурсе национальной безопасности во многом подчинено более важным целям «реальной политики».

Ключевые ислам, радикальный исламизм, Россия, Чечня, Сирия, ваххабизм, терроризм, слова СССР, Афрганистан

\footnotetext{
${ }^{*}$ Noa Gur-Arie (USA) is the Institute for International Law and Justice Scholar, New York University School of Law. Ноа Гур-Арие (США) - стипендиат Института международного права и правосудия, факультет права Нью-Йоркского университета, США.
} 


\section{Introduction: a new enemy?}

On 28 September 2015, two days before the Russian Air Force began conducting airstrikes in the Syrian Arab Republic, Russian President Vladimir Putin stood before the 70th session of the United Nations General Assembly in New York and called upon the world's leaders to remember their history. "In 1945, the countries that defeated Nazism joined their efforts to lay solid foundations for the postwar world order," Putin said. "I remind you that the key decisions on the principles guiding the cooperation among states, as well as on the establishment of the United Nations, were made in our country, in Yalta, at the meeting of the anti-Hitler coalition leaders." In his speech, Putin laid the groundwork for a new coalition, this time to fight a different enemy on a different stage: the Islamic State in Syria and Iraq (ISIS or IS). Just like the Allied Powers in World War II, this new coalition would "unite a broad range of forces that are resolutely resisting those who... sow evil and hatred of humankind". 1

In his speech, Putin emphasized that the Islamic State and its ilk were not new opponents for Russia: he cited his country's own more recent history of "consistently fighting terrorism." The speech is a specimen of the global "war on terrorism" national security discourse which uses terrorism as a shorthand for "Islamist political violence" and neatly elides the many differences and tensions between different Islamist groups and various forms of political violence to serve a specific discursive end. Putin implied that Russia was uniquely equipped to come to the aid of Bashar al-Assad's regime in Syria and confront "the Islamic state and other terrorist organizations" not only because of its demonstrated leadership in the 20th-century fight against fascism, but also because of its singular experience fighting terror at home. Although Putin did not go into detail about the history of Islamist insurgency in Russia and the bloody North Caucasian conflicts of the 1990s and 2000s, he referenced a concern clarified elsewhere that anything short of alignment with Assad presented a domestic threat to Russia: "We cannot allow these criminals who already tasted blood to return back home and continue their evil doings". The day before, on an American television program, he had been more specific: "More than 2000 fighters from Russia and ex-Soviet Republics are in the territory of Syria. There is a threat of their return to us. So, instead of waiting for their return, we are better off helping Assad fight them on Syrian territory".

This rhetoric was used to justify the Russian intervention in Syria. Still, while counterterrorism was one of Russia's motivations, it was hardly the only one and might not have even been the main one: as argued by many, the intervention primarily sought to prevent another instance of Western-backed violent regime change, in post-Libya context, and, at least at the time, to also force Russia's way back into dialogue with the international community, in post-Crimea crisis context, through a power play in a strategically significant region. ${ }^{3}$ In general, Russian foreign policy preceding the Syrian intervention had been characterized by a transition from aggressive anti-Islamism to greater acceptance of certain Islamist movements as part of pluralistic divisions of power, as in Palestine and Lebanon. Regardless, the Islamist terrorism threat has remained in the foreground of official discourse on Syria from the 2015 intervention through the declaration of "victory" against ISIS in 2017 and up to present-day confrontations with militant groups like "Hayat Tahrir al-Sham" in Idlib. ${ }^{4}$ Because of this, it remains worthwhile to examine the recent history of this narrative in Russia. Although Islamophobia is a global phenomenon woven deeply into the fabric of 
21st-century national security discourse which predates the attacks of September 11, 2001 in the United States, understanding how perceptions of the "Islamist threat" have manifested themselves in Russia over the past decades provides important context, as Russia continues to play a role in (re)building state structures in Syria, Libya and beyond.

Putin's apparent concern over radicalized Russian Muslims fighting in Syria has parallels in the late Soviet period, predating the wars in Chechnya. As part of its engagement in the Islamic world, both the Soviet Union and the Russian Federation instrumentalized their native Muslim populations to present a dichotomy between "good," assimilated, moderate Muslims and "bad" extremists. Although a relatively minor aspect of the national security discourse, it still bears examination as it persists into the present day and informs the Russian government's interactions with domestic and foreign Muslims.

Mahmood Mamdani, in his 2004 exploration of the roots of modern terrorism and Islamophobia, "Good Muslim, Bad Muslim", describes the Global War on Terrorism - and specifically the September 11 attacks - as "the unfinished business of the Cold War". ${ }^{5} \mathrm{He}$ refers to a legacy of violence and propaganda that has created the Western understanding of Islam today. This is largely a consideration of America's relationship to radical Islam as a counter-Communist force during the Cold War, particularly in the Middle East and in Southwest Asia: once mobilized against the existential threat of the Soviet Union, Islam subsequently came to replace it as the dominant "other" against which the West defined itself. After 9/11, Mamdani argues, American Muslims were obliged to justify their existence as "good Muslims," joining in a war against "bad Muslims." A similar dichotomy emerged in counterterrorism discourse in Russia and the former Soviet Union since the Soviet invasion of Afghanistan and through the present day.

\section{II. "Good” Russian Muslims and "bad" Russian Muslims}

Russia's intervention in Syria was its first military excursion in a faraway theatre of war since the 1979 Soviet invasion of Afghanistan. ${ }^{6}$ There, the Soviet Union was also explicitly confronting an Islamist threat: Soviet troops invaded to quash a rebellion by mujahidin guerrilla fighters threatening the pro-Moscow government. The United States, Saudi Arabia and Pakistan funded and armed those rebels, some of whom would later be declared enemies of both Russia and the United States as members of al-Qaeda and the Afghan Taliban.

At the time, Islam in Russia was officially organized in a system of regional governing bodies established as part of Josef Stalin's larger program of religious reform, following the repressions of the 1930s. In their domestic role, these Muslim Religious Boards represented a continuation of fumbling Russian imperial attempts to create a hierarchical, bureaucratic, and therefore more easily controlled "church for Islam", borrowed directly from the model of the Muslim Spiritual Assemblies established by Catherine II in the 1780s. ${ }^{7}$ Although nominally independent and funded by donations of believers, the Religious Boards answered to a Moscow-based governing body. The Religious Board for Central Asia and Kazakhstan, which was the largest and most influential of the four, published an official magazine in Uzbek, Arabic, English and French which served as a mouthpiece for "officially sanctioned" Soviet Islam. ${ }^{8}$ As the Afghan invasion proved increasingly unpopular in the Muslim world, souring relationships with some post-colonial Arab states (which had been carefully cultivated under the leadership of Nikita Khrushchev), the official representatives of 
Soviet Islam responded to the events through this magazine. In the first issue of 1980, the head Mufti of the Religious Board, Ziyovuddin Babakhanov, presented a philosophy of "progressive Islam" in opposition to the fundamentalist precepts of the mujahidin. A true "reversion to the teachings of the Holy Qur'an", Babakhanov asserted, does not entail the renunciation of modernity, but rather demands learning from it and from the wider world, Muslim and non-Muslim: "The present-day Muslim in fact imbibed into himself all the experiences and knowledge of his predecessors and was given the opportunity to analyze all valuable experiences which were achieved by various other nations". 9

Decades later, Russian Muslim leaders have mobilized in similar ways to lend legitimacy to Russian efforts in Syria. The Head of the Chechen Republic, Ramzan Kadyrov is probably Russia's most famous Muslim, although he is not technically a religious leader like, for example, Grand Mufti Ravil' Gaynutdin. Kadyrov frequently presents himself on the world stage - and is presented by the Kremlin - as the voice of Russian Islam. In 2016, after it was reported that two battalions of military police from Chechnya were being deployed to Syria, Kadyrov wrote on social media that he would eagerly join forces to combat international terrorism and "would be happy and proud to immediately go to Syria to fight the scum". ${ }^{10}$ Ramzan Kadyrov's father, Akhmad Kadyrov, had supported calls for jihad against Russia during the First Chechen War in 1994, but subsequently aligned himself with Moscow in the Second Chechen War. Elected President of Chechnya in 2003 and supported by the Kremlin as part of its Chechenization policy, Kadyrov senior became a vocal opponent of foreign, fundamentalist "Wahhabi" influence - an earlier version of the "scum" - that was held to undermine Chechnya's relatively moderate Sufi tradition. His son Ramzan would take up this mantle after his father's assassination months later. It is back in the 1980s, within a few years of the publication of the article in "Muslims of the Soviet East" promoting a vision of civilized and cosmopolitan Soviet Islam, that the term "Wahhabi" had entered the parlance of then-Soviet leaders as a shorthand for the opposite of this vision "fundamentalist," regressive strains of Islamic theology and practice deemed unacceptable and subversive.

\section{From Afghanistan to the North Caucasus: the rise of "Wahhabism" in Russia}

"Wahhabism" is a term usually used to refer to followers of the 18th century Najdi religious leader Muhammad ibn 'Abd al-Wahhab who declared all religious practices that deviated from the Qur'an and Hadith ${ }^{11}$ to be heresy. Al-Wahhab allied with the founder of the First Saudi State, Muhammad bin Saud, in a pact advantageous to both parties, and AlWahhab's precepts would become the state theology of the Kingdom of Saudi Arabia. Acolytes tend to refer to themselves more readily as "Muwahiddun" (believers in the oneness of God, or "Tawhid") rather than Wahhabis, but the latter term was being used by critics of Al-Wahhab's doctrine from as early as the 19th century, when British colonizers employed it to denigrate the Islamic organizations mobilizing against the British rule in India. ${ }^{12}$ In the Arab world as in the former Soviet Union, "Wahhabi" is often used alongside or interchangeably with the term "Salafi" that literally refers to a follower of the generation of the first Muslims. The boundaries of Salafi and Wahhabi are blurred in both Islamic religious history and taxonomies of national security discourse: in 2018, Saudi Crown Prince Muhammad Bin Salman said that "no one can define Wahhabism". ${ }^{13}$ This is certainly the case in the post-Soviet space where the "Wahhabi" label has been used more freely than in 
the West to refer to aberrant or subversive Islamic practices. The terms "Islamism" and "extremism" have gradually lost their specificity in similar ways: the former term technically refers to political movements informed by Islamic fundamentalist precepts, but it is often muddled with the nebulous threat evoked by the latter).

In those post-Soviet regions where Sufi traditions dominated, the prevailing "madhhab", or school of Islamic jurisprudence, was Hanafi, which is traditionally more open to discourse on new religious ideas than the strict traditionalist Hanbali madhhab with which Wahhabism is aligned. Hanafi Sufism was promoted as the acceptable form of practice, celebrated in nationalistic terms and frequently against interloping Wahhabism. There are conflicting theories as to the origins of this phenomenon. Alexander Knysh posits the growth in the use of the "Wahhabi" label around the fall of the Soviet Union as an attempt by secular post-Communist regimes to overcome their lack of Islamic legitimacy: the cultural and scientific achievements of Islamic civilization and traditional regional practices were celebrated as objects of national pride while Wahhabism, a philosophy centered on the rejection of religious "innovations," was itself presented as a deviant innovation and a malign foreign incursion. ${ }^{14}$ In the 1990 s and early 2000 s, the term was deployed to silence all political criticism with Islamic inflections. It was far more useful as a means of undermining opposition than as a precise theological term. Knysh emphasizes the political expedience of such a label, with its invocations of menacing fanatics cloaked in black: "One might venture a guess that if Wahhabism had never existed, presidents Karimov of Uzbekistan, Shaymiev of Tatarstan and their colleagues in the Northern Caucasus would have invented it. Or perhaps, invent it they did?"15

Although the protracted war in Afghanistan was influential in the establishment of this paradigm, it is the conflicts in the North Caucasus which played the greatest role in shaping it. The Chechen Wars fundamentally shaped the image of Islam and state policy towards it in the early years of the Russian Federation and continue to reverberate in Russia's domestic and foreign policy. Notably, though, Chechnya's Islamic heritage and the concept of political Islamism played only minor roles in the early years of the conflict. The "jihadist" and "Wahhabi" labels are often retroactively applied to the first years of post-Soviet Chechen resistance even though they were rarely invoked at the time. As Knysh notes, they remain important markers in Muslim communities in Tatarstan and post-Soviet Central Asia.

When Russian President Boris Yeltsin launched a major military operation against the self-declared independent Chechen Republic of Ichkeria in 1994, Chechnya was largely secular. ${ }^{16}$ The post-Soviet Islamic revival was in its infancy, but the 1994 conflict accelerated it, providing Islamist leaders an opportunity to harken back to the region's pre-Soviet heritage. As Moshe Gammer writes, "the war enhanced the Islamic dimension of mainly (but not only) Chechen identity. It brought to the fore memories of the Islamic resistance to Russia in the eighteenth and nineteenth centuries in Chechnya, in Dagestan and in other parts of the Caucasus. Most important, the war triggered the Islamization of politics in Chechnya and it catapulted the 'Wahhabis' and their ideology into center stage of both republics". 17

In 1995, the "Wahhabi" specter of the Chechen Wars entered the conflict. Unlike the vast majority of the Muslims against whom this label would be deployed in post-Soviet Russia, this variety was, indeed, of Saudi origin. Saudi-born Samir Saleh Abdullah, known as Emir Khattab, would become one of the most feared commanders to confront Russian forces in both Chechnya and Dagestan. ${ }^{18}$ His story, like that of many of the foreign fighters 
involved in such conflicts, began years earlier in Afghanistan. The country became a training camp for militants devoted to what they conceived of as a holy struggle, or jihad. After Soviet troops withdrew in 1988-1989, these men dispersed across Southwestern Asia and Eurasia, often in search of new battlegrounds. ${ }^{19}$ Although a ceasefire was signed in August 1996 that technically ended the First Chechen War, after the Taliban came to power in Afghanistan in the following month, Russian leadership began complaining that Afghan-trained militants like Khattab were moving into Chechnya en masse. In addition to "Wahhabi," these foreign fighters were sometimes simply referred to as "Afghans," although they came from all over the world. Khattab and the Chechen commander Shamil Basayev were declared to have "hundreds" of Arabs and other foreign "Wahhabis" among their forces. ${ }^{20}$ These figures have never been verified.

In 1997, Aslan Maskhadov was elected president of unrecognized Ichkeria. Although he had competed in the elections by promoting his Islamic credentials, he was quickly undermined by his more radical rivals - most prominently Basayev - who mobilized to unite Dagestan and Chechnya as a single "Islamic nation". ${ }^{21}$ Maskhadov quickly found use for the "Wahhabi" label to undermine these opponents as a group. As usual, he implied that they were foreign, although he also suggested that they were specifically allied with the Russian government - an ironic discrepancy, given the Russian government's own fixation on confronting foreign Islamists in the North Caucasus. ${ }^{22}$ The typical narrative of the Second Chechen War is that it began with a Chechen militant invasion of Dagestan. However, as Miriam Lanskoy points out, it was more precisely the arrival of Dagestani radicals into Chechnya which facilitated the consolidation of forces that sought to seize power in Dagestan and triggered the Russian intervention. ${ }^{23}$

In fact, the "Wahhabi" specter had been more central to the public conversation around Islam in Dagestan than in Chechnya up to that point. In the late 1990s, the voice of official Islam in Dagestan, Mufti Saídmuhammad-Haji Abubakarov, repeatedly declared that "a believer who kills a Wahhabi will get into paradise, as will a believer who is killed by a Wahhabi", effectively encouraging jihad against the proponents of jihad. ${ }^{24}$ In 1997, the Russian Duma passed the Law on the freedom of conscience. The law itemized offenses that could serve as the basis for the liquidation of a religious organization, including "violations of safety and public order" and "actions aimed at carrying out extremist activity. ${ }^{25}$ Dagestan quickly passed its own version of the law which was even more severe and specifically targeted "Wahhabi" organizing in the republic. ${ }^{26}$ Chechen president Maskhadov, increasingly threatened by Basayev, Khattab and their allies, issued a similar decree against "dissident and hostile" forms of Islam in the same year. He was supported in this campaign by his future successor, Akhmad Kadyrov, who was Chechnya's Chief Mufti at the time. ${ }^{27}$

After Chechen militants entered Dagestan, Russia began its second campaign in Chechnya. A series of bombings in residential buildings in Moscow, Volgodonsk and Buynaksk lent further urgency to the operation. Although Russia had established direct rule over the region by May 2000, the Islamist resistance persisted, and the government's attempts to target religious dissidence beyond the battlefield intensified. Wahhabism was officially "banned" in Dagestan in September 1999, though no official definition was provided for the term. ${ }^{28}$ Similar legislation against "extremism" failed to pass in the State Duma due to its vagueness; the Dagestani parliament's attempts to federalize their local law also fell through in 2000 and $2001 .^{29}$ 
However, the attacks of September 11, 2001 in the United States would shift the conversation. 9/11 represented the point of convergence for Russian and American antiIslamist discourses and ultimately provided the ideological ammunition that Putin would use in his 2015 United Nations General Assembly speech to justify Russia's calls for an international antiterrorist coalition in Syria.

\section{From the Chechen "Wahhabis" to international terrorists: 9/11 to Syria}

Although the notion of "Wahhabism" and larger percolating fears of the Islamist threat had entered the Russian political landscape prior to September 11, the launch of the American "war on terror", as George W. Bush first called it in his speech to Congress days later, helped to firmly instill fears of "Islamic terrorism" in a greater proportion of the Russian public and lent legitimacy to the new Putin administration's campaign against it not only in the North Caucasus, but throughout the Russian Federation. ${ }^{30}$ Putin's government quickly drew connections between the Chechen rebels and al-Qaeda, claiming that militants linked to Osama bin Laden were among those fighting Russian troops. ${ }^{31}$ The United States, for its part, was quick to do an about-face on the Chechen issue. While influential figures such as Condoleeza Rice and Zbigniew Brzezinski had at one point portrayed the Chechen separatists as "freedom fighters," the post-9/11 Bush administration conceded that the North Caucasus was a legitimate Russian front in "the war on terror", and the U.S. media reported that American soldiers were confronting Chechens, among others, in Afghanistan. ${ }^{32}$

In 2002, a new federal law on "combating extremist activity" was passed in Russia. ${ }^{33}$ The Dubrovka theatre siege of that year once again heightened the stakes; foreign Muslim organizations and charities were banned. ${ }^{34}$ However, at the same time, use of the "Wahhabi" label by both federal and Dagestani authorities began to recede as it was increasingly viewed as pejorative and perhaps harmful to Russian-Saudi relations. ${ }^{35}$ It was also part of a larger shift in Russian policy that began with the U.S. invasion of Iraq in 2003, which Russia strongly opposed, ending the rapprochement brought about by $9 / 11 .{ }^{36}$ While the conflict in Chechnya continued to be marked by excessive use of force and civilian casualties, the Kremlin also embarked on a public relations campaign in the Muslim world. Government officials stressed Russia's multiethnic heritage on the world stage, as it had frequently been done in the Soviet era, and provided support to loyal, moderate Islamic institutions domestically. Although Russia's Muslim population is obviously considerably less than that of the former Soviet Union as a whole, it remains the largest in Europe and is estimated at anywhere from 10 to 25 million people as of $2018 .^{37}$ President Putin declared that Russia "is to a significant extent a part of the Muslim world", and Russia became an observer member of the Organization of the Islamic Conference. ${ }^{38}$

These types of statement continued through the end of the Second Chechen War around 2009. In 2005, Russian presidential administration requested that state television replaces the word "Wahhabi" with "Islamic extremist," "jihad" with "subversive/terrorist activity", and even "Chechen terrorism" with "international terrorism" (the latter modification reflected continuing general alignment of Russia's domestic counterterrorism efforts with the U.S.-led "global war on terror", despite growing disagreements over Iraq). ${ }^{39}$ Although Ramzan Kadyrov persisted in his criticism of "Wahhabis" in Chechnya, Putin went so far as to explicitly walk back from his own previous condemnations of this amorphous group: in January 2006, he stated that "Wahhabism in itself does not pose any threat, but distortion of 
the norms of Islam, of Wahhabism, this of course cannot be viewed as anything other than calling for terrorism". ${ }^{40}$ In 2009, at the Arab League summit in Cairo, then-President Dmitry Medvedev proclaimed that Russia "has no need to seek friendship with the Muslim world, because our country is an organic part of this world". ${ }^{41}$ This was seemingly a response to U.S. President Barack Obama's speech made in the same city earlier that month, in which Obama explicitly sought "a new beginning between the United States and Muslims around the world, one based on mutual interest and mutual respect". ${ }^{42}$ Russia, as now suggested by the Kremlin, was in no need of renewing ties with a community to which it already belonged. Putin would reiterate this at a ceremony in Ufa in 2013, calling Islam "a striking element of the Russian cultural code, an inalienable, organic part of the Russian history". ${ }^{4}$

\section{Conclusion}

All this is to illustrate the gulf across which Putin reached, when, in 2015, he asked for the help of the international community in combating terrorism in Syria. As the United States under Obama shifted from the "global war on terror" model to "countering violent extremism," or CVE, Russian policymakers would remain more sensitive to extremism in all forms. ${ }^{44}$ While the United States had been fighting terror beyond its borders for nearly two decades, supported by the United Kingdom, France, and other NATO member states, Syria represented Russia's first international military commitment to this now decades-old struggle - a struggle that Putin, in his speech, framed simultaneously as a sort of eternal conflict between the powers of good and evil, going back to World War II, and as a more recent, but still historically grounded battle with the forces of "radical Islam" that might be traced back to the invasion of Afghanistan.

It might be traced back even further, though, to Soviet anti-religious campaigns against "Sufi fanatics": now upheld as synonymous with traditional, moderate Islam in many parts of the former Soviet Union, Sufism was once itself a threatening specter. ${ }^{45}$ Or perhaps we might look even further back, to Tsarist Russia's campaigns against members of the Sufi Naqshbandiyya tariqat who sought to resist colonization of the North Caucasus in the 1800s. As Dominic Rubin writes, "Chechen Sufism, or muridism as it was dubbed by the tsarist and then Soviet authorities, was the Wahhabism of its day". "Ironically, it seems to be members of a Sufi wird in Chechnya who were first labeled as Wahhabis by Soviet special services in the 1970 s. $^{47}$

The arbitrary quality of the Sufi/Wahhabi divide, and the "national Muslim vs. international terrorist" dichotomy that it has been supplanted by, reflects the slippery ways in which the threat of Islamic terrorism has been invoked to obscure more important realpolitik aims in Russia, just as the more general "good Muslim vs. bad Muslim" divide has been instrumentalized in the United States and elsewhere. In 2015, analysts found that almost 80 percent of Russia's declared targets in Syria were in areas not held by the Islamic State: rather, they were primarily in areas held by other Islamist opposition groups. ${ }^{48}$ This was not much of a surprise for most observers. Although Russia has played a lead role in dismantling genuinely malevolent Islamist militant organizations in Syria, the Islamic State chief among them, this has come at an enormous cost in civilian lives, much like its campaigns in the North Caucasus. Ultimately, although official Russian narratives about Islam and Islamism are important in understanding Russia's engagements in the Muslim world, they can only tell us so much. 


\section{ENDNOTES}

${ }^{1}$ Read Putin's U.N. General Assembly speech // The Washington Post. 28 September 2015.

${ }^{2}$ Katz M.N. Assessing Putin's "fight them there not here" strategy in Syria // Atlantic Council blog. 28.09.2015. URL: https://www.atlanticcouncil.org/blogs/syriasource/assessing-putin-s-fight-them-there-not-here-strategy-insyria (accessed 01.09.2021).

${ }^{3}$ See, e. g., Stepanova E. Russia's Foreign and Security Policy in the Middle East: Entering the 2020s. - Rome: Instituto Affari Internazionali, 2020. P. 5. URL: https://www.iai.it/sites/default/files/iaip2016.pdf (accessed 15.09.2021).

${ }^{4}$ Isachenkov V. Putin declares victory on visit to air base in Syria // Associated Press. 11.11.2017. https://apnews.com/article/8c15d4db5abd4d7d876927f3f099ab5a; Militants in Syria plotting provocation: Ministry of Defense of the Russian Federation // TASS. 23.05.2021. URL: https://tass.com/russia/1292883 (both accessed 14.08.2021).

${ }^{5}$ Mamdani M. Good Muslim, Bad Muslim: America, the Cold War, and the Roots of Terror. - New York: Three Leaves Press, 2005. P. 13.

${ }^{6}$ Putin gets permission to deploy Russian military in Syria // Deutsche Welle. 30.09.2015. http://www.dw.com/en/putin-gets-permission-to-deploy-russian-military-in-syria/a-18750396 (accessed 14.08.2021).

${ }^{7}$ Crews R.D. For Prophet and Tsar: Islam and Empire in Russia and Central Asia. - Cambridge, Mass.: Harvard University Press, 2009. P. 31; Khalid A. Islam After Communism: Religion and Politics in Central Asia. - Berkeley: University of California Press, 1999. P. 78.

${ }^{8}$ Ro'i Ya. Islam in the Soviet Union: From the Second World War to Gorbachev. - New York: Columbia University Press, 2000. P. 168.

${ }^{9}$ Babamuhamedov H.P.B. Muslims of our country today // Muslims of the Soviet East. 1980. № 1. P. 13.

${ }^{10}$ Chechen leader claims his troops eager to fight "scum" in Syria // The Guardian. 8 December 2016.

${ }^{11}$ Hadith (Arabic) is the record of the traditions or sayings of the Prophet Muhammad, revered as a major source of religious law and moral guidance, second only to the authority of the Qur'an.

${ }^{12}$ Ethno-Nationalism, Islam and the State in the Caucasus: Post-Soviet Disorder. Ed. M.Gamer. Central Asian Studies Series № 9. - London: Routledge, 2008. P. 192 (note 20).

${ }^{13}$ Goldberg G. Saudi Crown Prince: Iran's Supreme Leader "makes Hitler look good" // The Atlantic. 2 April 2018. URL: https://www.theatlantic.com/international/archive/2018/04/mohammed-bin-salman-iran-israel/557036 (accessed 01.09.2021).

${ }^{14}$ Knysh A. A clear and present danger: "Wahhabism” as a rhetorical foil // Die Welt Des Islams. 2004. V. 44. № 1. P. 17.

15 Ibid. P. 18.

${ }^{16}$ Gammer M. Between Mecca and Moscow: Islam, politics and political Islam in Chechnya and Daghestan // Middle Eastern Studies. 2005. V. 41. № 6. P. 836. 
17 Ibid.

18 Bakke K. M. Copying and learning from outsiders? Assessing diffusion from transnational insurgents in the Chechen wars // Transnational Dynamics of Civil War. Ed. J.T.Checkel. - Cambridge: Cambridge University Press, 2013. P. 16.

19 Yemelianova G.M. Islamic radicalisation: a post-Soviet, or a global phenomenon? // Radical Islam in the Former Soviet Union. Ed. G.M.Yemelianova. Routledge Contemporary Russia and Eastern Europe Series № 18. - London: Routledge, 2010. P. 16.

${ }^{20}$ Hill F. Putin and Bush in common cause? Russia's view of the terrorist threat after September $11 / /$ The Brookings Review. 2002. V. 20. № 3. P. 34. URL: https://www.brookings.edu/articles/putin-and-bush-incommon-cause-russias-view-of-the-terrorist-threat-after-september-11 (accessed 01.09.2021).

${ }^{21}$ Gammer M. Between Mecca and Moscow. P. 837-838.

22 Ibid. P. 841.

${ }^{23}$ Lanskoy M. Daghestan and Chechnya // SAIS Review. 2002. V. 22. № 2. P. 168.

${ }^{24}$ Gammer M. Between Mecca and Moscow. P. 839.

${ }^{25}$ Federal'nyi zakon 26.09.1997 № 125-FZ “O svobode sovesti i o reliogioznykh ob’yedineniyakh" ["On Freedom of Conscience and Religious Orgnizations"] (1997). Article 14. URL: http://www.consultant.ru/document/cons_ doc_LAW_16218/48efe087fd6db83d8644159dee55ed3abe168310 (accessed 18.08.2021).

${ }^{26}$ Lanskoy M. Op. cit. P. 177.

27 Gammer M. Between Mecca and Moscow. P. 841.

28 Malashenko A.V., Nuritova A. Islam in Russia // Social Research. 2009. V. 76. № 1. P. 342.

29 Verkhovsky A. Russian approaches to radicalism and "extremism" as applied to nationalism and religion // Russia and Islam: State, Society and Radicalism. Eds. R.Dannreuther and L.March. - L.; N.Y.: Routledge, 2010. P. 33.

30 Transcript of President Bush's address to a Joint Session of Congress on Thursday night, September 20, 2001 // CNN. 21.09.2001. URL: http://edition.cnn.com/2001/US/09/20/gen.bush.transcript (accessed 01.09.2021); Verkhovsky A. Op. cit. P. 31.

31 Russell J. Terrorists, bandits, spooks and thieves: Russian demonisation of the Chechens before and since 9/11// Third World Quarterly. 2005. V. 26. № 1. P. 101-116.

32 Williams B.G. Shattering the Al Qaeda-Chechen myth: part I // North Caucasus Weekly. 2003. V. 4. № 35. URL: https://jamestown.org/program/shattering-the-al-qaeda-chechen-myth-part-i-2 (accessed 10.08.2021).

33 Verkhovsky A. Op. cit. P. 34.

34 Dannreuther R. Russian discourses and approaches to Islam and Islamism // Russia and Islam: State, Society and Radicalism. Eds. R.Dannreuther and L.March. - L.; N.Y.: Routledge, 2010. P. 16. 
35 Matveeva A. Daghestan: inter-ethnic tensions and cross-border implications // The Caspian Region. Ed. M.Gammer. V. 2: The Caucasus. - L.: Routledge, 2004. P. 127.

${ }^{36}$ Ambrosio T. The Russo-American dispute over the invasion of Iraq: international status and the role of positional goods // Europe-Asia Studies. 2005. V. 57. № 8. P. 1189.

37 Islam in Russia // Aljazeera. 07.03.2018. URL: https://www.aljazeera.com/features/2018/3/7/islam-in-russia (accessed 01.09.2021).

38 Dannreuther R. Op. cit. P. 16-17.

39 Fagan G. Russia: Islamic extremists, real and imagined // Forum 18 News Service. 08.08.2007. URL: https://www.refworld.org/pdfid/46bac02f2.pdf (accessed 15.09.2021).

40 Ibid.

41 Medvedev D. Speech at Meeting of the Permanent Representatives of the League of Arab States. 23 June 2009. URL: http://www.en.kremlin.ru/catalog/countries/EG/events/4804 (accessed 01.09.2021).

42 Obama B. The President's Speech in Cairo: A New Beginning. 4 June 2009. - Washington D.C.: The White House, 2009. URL: https://obamawhitehouse.archives.gov/issues/foreign-policy/presidents-speech-cairo-a-new-beginning (accessed 15.09.2021).

43 Crews R.D. Moscow and the mosque: co-opting Muslims in Putin's Russia // Foreign Affairs. 2014. V. 93. № 2. P. 130.

${ }^{44}$ Stepanova E., Cragin K. Countering terrorism and violent extremism // A Roadmap for U.S.-Russia Relations. Eds. A.Kortunov and O.Oliker. - Lanham, MD: Rowman and Littlefield, 2017. P. 74.

${ }^{45}$ Atkin M. The rhetoric of Islamophobia // Central Asia and the Caucasus. 2000. № 1. P. 123-132.

46 Rubin D. Russia's Muslim Heartlands: Islam in the Putin Era. - London: Hurst \& Company, 2018.

47 Zelkina A. The "Wahhabis" of the Northern Caucasus vis-à-vis state and society: the case of Daghestan // The Caspian Region. Ed. M.Gammer. V. 2: The Caucasus. - L.: Routledge, 2004. P. 146-178.

48 Stubbs J. Four-fifths of Russia's Syria strikes don't target Islamic State // Reuters. 21.10.2015. URL: https://www.reuters.com/article/us-mideast-crisis-syria-russia-strikes/four-fifths-of-russias-syria-strikes-donttarget-islamic-state-reuters-analysis-idUSKCNOSF24L20151021 (accessed 15.09.2021).

\section{BIBLIOGRAPHY}

Ambrosio T. (2005). The Russo-American dispute over the invasion of Iraq: international status and the role of positional goods. Europe-Asia Studies. V. 57. No. 8. P. 1189-1210. DOI: $10.1080 / 09668130500351357$.

Atkin M. (2000). The rhetoric of Islamophobia. Central Asia and the Caucasus. No. 1. P. 123-132.

Babamuhamedov H. P. B. (1980). Muslims of our country today. Muslims of the Soviet East. No. 1. P. 13.

Bakke K. M. (2013). Copying and learning from outsiders? Assessing diffusion from transnational insurgents in the Chechen Wars. In: Transnational Dynamics of Civil War. Ed. J.T.Checkel. Cambridge: Cambridge University Press. P. 31-62. DOI: 10.1017/CBO9781139179089.005. 
Crews R. D. (2009). For Prophet and Tsar: Islam and Empire in Russia and Central Asia. Cambridge, Mass.: Harvard University Press. 480 p.

Crews R. D. (2014). Moscow and the mosque: co-opting Muslims in Putin's Russia. Foreign Affairs. V. 93. No. 2. P. $125-134$.

Dannreuther R. (2010). Russian discourses and approaches to Islam and Islamism. In: Russia and Islam: State, Society and Radicalism. Eds. R.Dannreuther and L.March. London; New York: Routledge. P. 9-25.

Dannreuther R. and March L. eds. (2010). Russia and Islam: State, Society and Radicalism. BASEES/Routledge Series on Russian and East European Studies no. 66. London; New York: Routledge. $272 \mathrm{p}$.

Gammer M. (2005). Between Mecca and Moscow: Islam, politics and political Islam in Chechnya and Daghestan. Middle Eastern Studies. V. 41. No. 6. P. 833-848. DOI: 10.1080/00263200500261829.

Gammer M. ed. (2008). Ethno-Nationalism, Islam and the State in the Caucasus: Post-Soviet Disorder. Central Asian Studies Series no. 9. London: Routledge. 254 p.

Hill F. (2002). Putin and Bush in common cause? Russia's view of the terrorist threat after September 11. The Brookings Review. 2002. V. 20. No. 3. URL: https://www.brookings.edu/articles/putin-andbush-in-common-cause-russias-view-of-the-terrorist-threat-after-september-11 (accessed 01.09.2021).

Khalid A. (1999). Islam After Communism: Religion and Politics in Central Asia. Berkeley: University of California Press. 253 p.

Knysh A. (2004). A clear and present danger: "Wahhabism" as a rhetorical foil. Die Welt Des Islams. V. 44. No. 1. P. 3-26. DOI: 10.1163/157006004773712569.

Lanskoy M. (2002). Daghestan and Chechnya. SAIS Review. V. 22. No. 2. P. 167-192.

Malashenko A. V. and Nuritova A. (2009). Islam in Russia. Social Research. V. 76. No. 1. P. 321-358.

Mamdani M. (2005). Good Muslim, Bad Muslim: America, the Cold War, and the Roots of Terror. New York: Three Leaves Press. 320 p.

Matveeva A. (2004). Daghestan: inter-ethnic tensions and cross-border implications. In: The Caspian Region. V. 2: The Caucasus. Ed. M.Gammer. London: Routledge. P. 122-141.

Ro'i Ya. (2000). Islam in the Soviet Union: From the Second World War to Gorbachev. New York: Columbia University Press. $764 \mathrm{p}$.

Rubin D. (2018). Russia's Muslim Heartlands: Islam in the Putin Era. London: Hurst \& Company. 288 p.

Russell J. (2005). Terrorists, bandits, spooks and thieves: Russian demonisation of the Chechens before and since 9/11. Third World Quarterly. V. 26. No. 1. P. 101-116.

DOI: $10.1080 / 0143659042000322937$.

Stepanova E. (2020). Russia's Foreign and Security Policy in the Middle East: Entering the 2020s. Rome: Instituto Affari Internazionali. 25 p. URL: https://www.iai.it/sites/default/files/iaip2016.pdf (accessed 15.09.2021).

Stepanova E. and Cragin K. (2017). Countering terrorism and violent extremism. In: A Roadmap for U.S Russia Relations. Report of the Center for Strategic and International Studies Russia and Eurasia Program and Russian International Affairs Council. Eds. A.Kortunov and O.Oliker. Lanham, MD: Rowman and Littlefield. P. 73-81.

Verkhovsky A. (2010). Russian approaches to radicalism and "extremism" as applied to nationalism and religion. In: Russia and Islam: State, Society and Radicalism. Eds. R.Dannreuther and L.March. London; New York: Routledge. P. 26-43.

Williams B. G. (2003). Shattering the Al Qaeda-Chechen myth: part I. North Caucasus Weekly. V. 4. No. 35. URL: https://jamestown.org/program/shattering-the-al-qaeda-chechen-myth-part-i-2.

Yemelianova G. M. (2010). Islamic radicalisation: a post-Soviet, or a global phenomenon? In: Radical Islam in the Former Soviet Union. Ed. G.M.Yemelianova. London: Routledge. P. 11-31.

Yemelianova G. M. ed. (2010). Radical Islam in the Former Soviet Union. Routledge Contemporary Russia and Eastern Europe Series no. 18. London: Routledge. 300 p.

Zelkina A. (2004). The "Wahhabis" of the Northern Caucasus vis-à-vis state and society: the case of Daghestan. In: The Caspian Region. V. 2: The Caucasus. Ed. M.Gammer. London: Routledge. P. 146-178. 